\title{
ANALISIS FAKTOR YANG MEMPENGARUHI PRESTASI BELAJAR MAHASISWA JURUSAN KEBIDANAN RANGKASBITUNG ANGKATAN TAHUN 2017
}

\author{
Tutik Iswanti \\ Jurusan Kebidanan Poltekkes Kemenkes Banten \\ E-mail : tutik8375@gmail.com
}

\begin{abstract}
Learning achievement is an important indicator for measuring success teaching and learning process. The purpose of learning is a changed behavior that is expected to be achieved by someone after doing something learning process. This study aims to analyze factors that affect the learning achievement of year-old midwifery students in 2017. This research uses a descriptive method with cross design sectional. The number of samples in this study was 86 respondents taken with total sampling technique. Analysis of univariate data is presented using tables of frequency distribution and bivariate analysis with statistical tests fisher test. The results obtained were students with less GPA in the Department midwifery is $88.4 \%$, more of which are from high school, which is equal to $79.1 \%$, students with general track entry of $80.2 \%$ and students with the value of a good school exam is 51.2\%. There are no influencing factors learning achievement (GPA), namely school origin (0.681), entry point (0.679) and grades school exam (0.315). Learning achievement is not influenced by three factors, namely school origin, entrance, and school exam scores.
\end{abstract}

Keywords: Learning achievement, students

\begin{abstract}
ABSTRAK
Prestasi belajar merupakan indikator yang penting untuk mengukur keberhasilan proses belajar mengajar. Tujuan dari pembelajaran adalah suatu perubahan tingkah laku yang diharapkan tercapai oleh seseorang setelah melakukan suatu proses pembelajaran. Penelitian ini bertujuan untuk menganalisis faktor-faktor yang mempengaruhi prestasi belajar mahasiswa jurusan kebidanan angkatan tahun 2017. Penelitian ini menggunakan metode deskriptif dengan rancangan cross sectional. Jumlah sampel pada penelitian ini sebanyak 86 responden yang diambil dengan teknik total sampling. Analisis data univariat dipaparkan dengan menggunakan tabel distribusi frekuensi dan analisis bivariat dengan uji statistik uji fisher. Hasil yang didapat adalah mahasiswa dengan IPK kurang di Jurusan kebidanan sebesar $88,4 \%$, lebih banyak yang dari SMA yaitu sebesar $79,1 \%$, mahasiswa dengan jalur masuk jalur umum sebesar $80,2 \%$ dan mahasiswa dengan nilai ujian sekolah baik sebesar 51,2\%. Tidak ada Faktor yang mempengaruhi prestasi belajar (IPK) yaitu asal sekolah $(0,681)$, jalur masuk $(0,679)$ dan nilai ujian sekolah (0,315). Prestasi belajar tidak dipengaruhi oleh ketiga faktor yaitu asal sekolah, jalur masuk dan nilai ujian sekolah.
\end{abstract}

\section{Kata kunci : Prestasi belajar, mahasiswa.}

\section{PENDAHULUAN}

Prestasi belajar merupakan indikator yang penting untuk mengukur keberhasilan proses belajar mengajar. Tujuan dari pembelajaran adalah suatu perubahan tingkah laku yang diharapkan tercapai 
oleh seseorang setelah melakukan suatu proses pembelajaran (Hamalik, 2014) dan menurut Yamin, tujuan pembelajaran merupakan sasaran yang hendak dicapai pada akhir pengajaran, serta kemampuan yang harus dimiliki seseorang (Yamin, 2007).

Dalam proses pembelajaran terdapat perbedaan prestasi antara mahasiswa satu dengan yang lainnya. Menurut Arikunto, memang tidak dapat dipungkiri bahwa tinggi rendahnya prestasi mahasiswa banyak dipengaruhi oleh faktor-faktor lain disamping proses mengajar (Arikunto, 2009).

Faktor-faktor yang dapat mempengaruhi perbedaan hasil belajar setiap mahasiswa adalah faktor internal dan faktor eksternal. Faktor internal meliputi faktor yang ada dalam diri individu yang sedang belajar. Faktor eksternal adalah faktor yang ada di luar individu. Banyak hal yang mencakup faktor internal dan faktor eksternal (Sugihartono, 2007).

Dari sekian banyak faktor yang mempengaruhi prestasi belajar, faktor sosial seperti karakteristik mahasiswa (asal sekolah, jalur tes masuk, dan nilai ujian sekolah), lingkungan keluarga, masyarakat dan kelompok memiliki peran yang penting dalam pencapaian prestasi belajar.

Sistem penerimaan mahasiswa baru di Jurusan kebidanan Poltekkes kemenkes Banten yaitu jalur PMDP (Penelusuran Minat Dan Prestasi) dan jalur umum (tes). Pada jalur PMDP berdasarkan pada hasil seleksi ujian masuk berdasarkan nilai Ujian sekolah, dengan latar belakang Sekolah Menengah Atas serta prestasi yang pernah diperoleh oleh calon mahasiswa. Disamping itu, Jurusan kebidanan Poltekkes kemenkes Banten juga menerima calon mahasiswa dari SMK dengan latar belakang kesehatan. Selain itu ada juga sistem penerimaan dengan jalur umum yaitu dengan jalur tes ujian masuk. Berdasarkan hasil tes masuk tadi, yang telah disaring sesuai dengan tuntutan Poltekkes, dimaksudkan agar mahasiswa yang telah diterima itu, memang memiliki motivasi belajar yang tinggi dan mampu berprestasi terutama di bidang pengajaran yang dibuktikan dengan Indeks Prestasi Kumulatif (IPK).

Berdasarkan uarian diatas, maka penelitian ini dirancang untuk mengetahui faktor-faktor yang mempengaruhi prestasi mahasiswa Jurusan Kebidanan Rangkasbitung angkatan tahun 2017. Tujuan dari penelitian ini yaitu untuk 
menganalisis faktor-faktor yang banyak yang dari SMA yaitu sebesar mempengaruhi prestasi belajar mahasiswa jurusan kebidanan angkatan tahun 2017.

\section{METODE}

Metode yang digunakan dalam penelitian ini adalah metode penelitian analitik dengan pendekatan cross sectional. Setiap subyek hanya dilakukan pengukuran satu kali yaitu pada saat dilakukan penelitian tersebut (Sastroasmoro \& Ismael, 2008).

Populasi dalam penelitian ini yaitu seluruh mahasiswa jurusan kebidanan Rangkasbitung tingkat II dengan jumlah sebanyak 86 mahasiswa. Dalam pemilihan sampel peneliti membuat kriteria inklusi dan kriteria eksklusi. Subyek yang memenuhi kriteria inklusi akan masuk dalam sampel penelitian.

\section{HASIL}

1. Analisa univariat

Tabel Distribusi frekuensi variabel penelitian

\begin{tabular}{llcc}
\hline Variabel & Kategori & $\begin{array}{c}\text { Frekuen } \\
\text { si }\end{array}$ & $\begin{array}{c}\text { Presentase } \\
(\boldsymbol{\%})\end{array}$ \\
\hline Asal Sekolah & Bukan SMA & 18 & 20,9 \\
& SMA & 68 & 79,1 \\
Jalur masuk & Umum & 69 & 80,2 \\
& PMDP & 17 & 19,8 \\
Nilai $\quad$ ujian & Kurang & 42 & 48,8 \\
sekolah & Baik & 44 & 51,2 \\
IPK & Kurang & 76 & 88,4 \\
& Baik & 10 & 10,6
\end{tabular}

Berdasarkan tabel diatas menunjukan bahwa mahasiswa dengan IPK kurang di Jurusan kebidanan sebesar $88,4 \%$, lebih

\begin{tabular}{|c|c|c|c|c|c|c|}
\hline \multirow{2}{*}{$\begin{array}{l}\text { Variabel } \\
\text { penelitian }\end{array}$} & \multicolumn{4}{|c|}{ IPK } & \multirow[t]{2}{*}{ P value } & \multirow{2}{*}{$\begin{array}{c}\text { CI } \\
(95 \%)\end{array}$} \\
\hline & $\begin{array}{c}\text { Kuran } \\
\mathbf{g} \\
\mathbf{N}\end{array}$ & $\%$ & $\begin{array}{c}\text { Baik } \\
\mathbf{N}\end{array}$ & $\%$ & & \\
\hline \multicolumn{7}{|l|}{ Asal Sekolah } \\
\hline Bukan SMA & 17 & 94,4 & 1 & 5,6 & 0,681 & $0,307-$ \\
\hline SMA & 59 & 86,8 & 9 & 13,2 & & 21,937 \\
\hline \multicolumn{7}{|l|}{ Jalur Masuk } \\
\hline Umum & 60 & 87,0 & 9 & 13,0 & 0,679 & 0,049 - \\
\hline PMDP & 16 & 94,1 & 1 & 5,9 & & 3,535 \\
\hline \multicolumn{7}{|l|}{ Nilai Ujian } \\
\hline \multicolumn{7}{|l|}{ Sekolah } \\
\hline Kurang & 39 & 92,9 & 3 & 7,1 & 0,315 & $0,591-$ \\
\hline Baik & 37 & 84,1 & 7 & 15,9 & & 10,23 \\
\hline
\end{tabular}

Berdasarkan hasil analisis bivariat pada tabel diatas didapatkan bahwa hubungan asal sekolah responden terhadap nilai IPK menunjukkan bahwa responden dengan asal sekolah SMA memiliki nilai IPK baik $13,2 \%$ lebih banyak dibanding bukan SMA, tetapi responden dengan asal sekolah bukan SMA memiliki nilai IPK kurang 94,4\% lebih banyak dibandingkan dengan asal sekolah SMA. Hubungan antara asal sekolah dengan nilai IPK pada mahasiswa Jurusan kebidanan angkatan tahun 2017 tidak terdapat hubungan yang bermakna (Pvalue $=0,681 ; \mathrm{CI}=0,307-21,937)$. 
Hubungan jalur masuk responden terhadap nilai IPK menunjukkan bahwa responden dengan jalur masuk PMDP memiliki nilai IPK baik 5,9\% lebih sedikit dibanding jalur umum dan responden dengan jalur masuk umum memiliki nilai IPK kurang 87,0\% lebih sedikit dibandingkan dengan jalur masuk PMDP. Hubungan antara jalur masuk dengan nilai IPK pada mahasiswa Jurusan kebidanan angkatan tahun 2017 tidak terdapat hubungan yang bermakna (Pvalue=0,679; CI=0,049-3,535).

Hubungan nilai ujian sekolah responden terhadap nilai IPK menunjukkan bahwa responden dengan nilai ujian sekolah baik memiliki nilai IPK baik 15,9\% lebih banyak dibanding dengan nilai ujian sekolah kurang, tetapi responden dengan nilai ujian sekolah kurang memiliki nilai IPK kurang 92,9\% lebih banyak dibandingkan dengan nilai ujian sekolah baik. Hubungan antara nilai ujian sekolah dengan nilai IPK pada mahasiswa Jurusan kebidanan angkatan tahun 2017 tidak terdapat hubungan yang bermakna $\quad($ Pvalue $=0,315 ; \quad \mathrm{CI}=0,591-$ 10,230).

\section{PEMBAHASAN}

Indeks Prestasi Kumulatif (IPK) adalah tingkat keberhasilan mahasiswa sejak semester pertama sampai semester tertentu/akhir dan dalam perhitungan IPK tersebut setiap mata kuliah hanya diperhitungkan sekali, apabila ada pengulangan mata kuliah, maka yang digunakan adalah nilai tertinggi.

Hasil analisis bivariat asal sekolah dengan nilai IPK mahasiswa jurusan kebidanan Poltekkes Kemenkes Banten memiliki hubungan yang tidak bermakna dengan $p$ value $=0,681 ; \mathrm{CI}=0,307-21,937$.

Hasil penelitian ini tidak sejalan dengan penelitian Ratna (2014) yang dilakukan di kabupaten Sumenep yang menyatakan bahwa ada hubungan yang signifikan antara asal sekolah dengan nilai IPK (Pvalue=0,009).

Asal sekolah merupakan variabel yang ada hubungannya atau bernilai tinggi pada hasil akhir prestasi belajar, dimana kemajuan sekolah juga mempengaruhi proses pembelajaran yang ditempuh selama perkuliahan, jika anak tersebut sudah biasa mendapat pelajaran ataupun kegiatan ekstra pada saat menempuh sekolah menengah maka mahasiswa tersebut akan menerima pelajaran saat perkuliahan berlangsung. Selama ini yang banyak diminati anak untuk masuk kesehatan yaitu brasal adari SMA. Namun saat ini tidak hanya dari SMA saja nanum MA juga diminati. 
Namun untuk saat ini tidak kalah pesatnya banyak lulusan SMK yang juga masuk kesehatan terutama dari SMK kesehatan.

Hasil analisis bivariat jalur masuk dengan nilai IPK mahasiswa jurusan kebidanan Poltekkes Kemenkes Banten memiliki hubungan yang tidak bermakna dengan $p$ value $=0,679 ; \mathrm{CI}=0,049-3,535$.

Hasil penelitian ini tidak sejalan dengan penelitian Setyoningsih (2003) dan Darobi (2008) yang menyebutkan bahwa terdapat hubungan yang bermakna antara jalur masuk dengan prestasi akademik. Minat kuliah mahasiswa yang kemudian menimbulkan motivasi selalu berpengaruh positif terhadap prestasi akademik. Hal ini sangat beralasan, mahasiswa yang diterima melalui jalur minat yaitu PMDP dinilai memiliki prestasi akademik yang memuaskan. Jadi mahasiswa yang menggunakan minat dan motivasi untuk melaksanakan proses perkuliahan akan memiliki rasa tanggung jawab yang lebih atas proses perkuliahan tersebut, sehingga kinerja akademik dinilai sangat memuaskan

Hasil ujian sekolah tidak perlu dijadikan tolok ukur kelulusan sekolah tetapi dijadikan acuan indeks peringkat sekolah sehingga tidak diperlukan batas ambang, berapapun hasil ujian sekolah yang ada ditulis pada ijazah. Namun hasil ujian tidak valid untuk menggambarkan prestasi sebuah sekolah. Ujian sekolah sebagai alat kontrol sekolah pada era otonomi masih diperlukan sepanjang tidak digunakan sebagai penentu kelulusan namun berfungsi layaknya instrumen penelitian.

Hasil analisis bivariat nilai ujian sekolah dengan nilai IPK mahasiswa jurusan kebidanan Poltekkes Kemenkes Banten memiliki hubungan yang tidak bermakna dengan $\quad p$ value $=0,315$; $\mathrm{CI}=0,591-10,230$.

Hasil penelitian ini sejalan dengan penelitian Hamka (2010) yang dilakung kan di Bogor yang menyatakan bahwa tidak ada hubungan antara rata rata ujian dengan IPK tiga semester pertama mahasiswa Jurusan Biologi angkatan tahun 2008/2009.

Ujian sekolah dilaksanakan sebatas menilai prestasi siswa dalam menguasai bahan ajar saat duduk di bangku sekolah lanjutan. Bahan ajar yang dimaksud adalah mata pelajaran yang di ujiankankan (misalnya matematika, biologi, fisika, kimia, bahasa Indonesia, bahasa Ingggris). Kalau nilai ujian bagus, bisa diartikan siswa sangat menguasai pelajaran SMA. Sedang tes masuk perguruan tinggi dilaksanakan untuk 
memprediksi keberhasilan seseorang ketika studi di perguruan tinggi. Yang diujikan bukanlah isi mata pelajaran ketika SMA. Tapi materi-materi yang menunjukkan potensi akademiknya. Kalau calon mahasiswa mendapatkan nilai ujian masuk perguruan tinggi bagus, maka dia diprediksi akan mendapatkan indeks prestasi (IP) yang bagus saat kuliah.

\section{SIMPULAN}

Adapun simpulan penelitian ini adalah IPK kurang di Jurusan kebidanan sebesar $88,4 \%$, lebih banyak yang dari SMA yaitu sebesar 79,1\%, mahasiswa dengan jalur masuk jalur umum sebesar 80,2\% dan mahasiswa dengan nilai ujian sekolah baik sebesar $51,2 \%$. Tidak ada faktorfaktor yang mempengaruhi prestasi belajar mahasiswa jurusan kebidanan angkatan tahun 2017.

\section{DAFTAR PUSTAKA}

Abdillah. Hubungan Jalur Penerimaan Mahasiswa Baru Akuntansi Terhadap Prestasi Akademik.

Ahmadi A, Widodo S. 2008. Psikologi Belajar. Jakarta: Rineka Cipta.

Arikunto, Suharsimi. 2009. Dasar-dasar Evaluasi Pendidikan. Jakarta: Bumi Aksara.

Dalyono. 2005. Psikologi Pendidikan. Jakarta : PT Rineka Cipta.

Daryanto. 2010. Media Pembelajaran. Yogyakarta: Gava Media.
Djamarah, Bahri S. 2008. Psikologi Belajar. Jakarta : Rineka Cipta.

Gilakjani, Pourhossein A. 2012. Visual Auditory, Kinaesthetic Learning Style and Their Impact on English Languege Teaching. Journal of Studies In Education 2 (1) : 104113.

Hakim T, 2010. Belajar secara Efektif

Hamalik O. 2014. Proses Belajar Mengajar. Jakarta : PT Bumi Aksara.

Hamka 2010. Hubungan antara rata-rata nilai UAN dengan IPK tiga semester awal mahasiswa jurusan biologi FMIPA UNM tahun akademik 2008/2009. Makasar : Bionature Vol. 11 (2): Hlm: 85 88, Oktober 2010 No. ISSN: 14114720

Nasution. 2009. Berbagai Pendidikan dalam Proses Belajar Mengajar. Jakarta: Bumi Aksara.

Ratna. 2014. Pengaruh Asal Sekolah Dan Tempat Tinggal Terhadap Prestasi Belajar Mahasiswa Prodi D III Kebidanan Universitas Wiraraja Sumenep. Surakarta: Universtias Sebelas Maret

Sardiman. 2005. Interaksi Dan Motovasi Belajar Mengajar. Jakarta : Raja Grafindo Persada.

Subini N. 2012. Mengatasi Kesulitan Belajar Pada Anak. Jogjakarta: Javalitera.

Sukadi. 2008. Progressive Learning. Bandung: MQS Publishing.

Widya, dkk. 2012. Faktor-Faktor Yang Mempengaruhi Hasil Belajar Mahasiswa Tingkat II Prodi D3 Kebidanan Stikes Mercubaktijaya Padang Tahun Ajaran 2011/2012. Padang

Yamin M. 2007. Desain Pembelajaran Berbasis Tingkat Satuan Pendidikan. Jakarta : Putra Grafika. 